\title{
MACROSCOPIC AND HISTOLOGICAL CHARACTERISTICS OF FLUID-FILLED OVARIAN STRUCTURES IN DAIRY COWS
}

\author{
Orsolya Gabriella BALOGH ${ }^{*}$, Ernő TÚRY ${ }^{2}$, Zsolt ABONYI-TÓTH ${ }^{3}$, John KASTELIC ${ }^{3}$ \\ and György GÁBOR ${ }^{1}$ \\ ${ }^{1}$ Research Institute for Animal Breeding and Nutrition, Gesztenyés u. 1, H-2053 \\ Herceghalom, Hungary; ${ }^{2}$ Department of Anatomy and Histology and ${ }^{3}$ Department of \\ Biomathematics and Informatics, Faculty of Veterinary Science, Szent István University, \\ Budapest, Hungary; ${ }^{4}$ Department of Production Animal Health, University of Calgary, \\ Calgary, Alberta, Canada
}

(Received 5 December 2012; accepted 2 April 2013)

The primary objective of this study was to use macroscopic and histological features of corpora lutea with a cavity and anovulatory cystic ovarian structures, present in 90 pairs of abattoir-derived dairy cow ovaries, as the basis to clarify the nomenclature of ovarian structures. Excluding morphologically normal ovarian follicles (antrum $<2 \mathrm{~cm}$, wall $<1 \mathrm{~mm}$ ), there were 27 fluid-filled ovarian structures. Ovulatory structures $>16 \mathrm{~mm}$ in diameter were designated as Group A (cavity $\leq$ $10 \mathrm{~mm}$ and wall $>10 \mathrm{~mm}$ ) or Group B (cavity $>10 \mathrm{~mm}$ and wall $<10 \mathrm{~mm}$ ). The volume of luteal tissue was less $(\mathrm{P}<0.05)$ in Group B than in Group A, whereas that of a solid corpus luteum (CL) was intermediate (least square means \pm SEM: $72 \pm 1.92,11.22 \pm 1.57$ and $5.84 \pm 1.92 \mathrm{~cm}^{3}$, respectively). There was a greater proportion $(\mathrm{P}<0.05)$ of small luteal cells in Group B compared to a solid CL, whereas Group A was intermediate $(58.6 \pm 5.3,37.4 \pm 5.3$ and $44.0 \pm 4.4 \%$, respectively). Connective tissue was thicker $(\mathrm{P}<0.05)$ in Group B than in Group A $(295.4 \pm 46.9$ vs. $153.9 \pm 38.2 \mu \mathrm{m})$. Based on the above-mentioned characteristics and differences, Groups A and B were designated as a CL with a cavity and a cystic CL, respectively. Furthermore, there were three groups of anovulatory ovarian structures. Structures in Group C were termed persistent/anovulatory follicles (overall diameter and wall thickness $\leq 20$ and $1-3 \mathrm{~mm}$, respectively). Finally, Groups D and E were designated as a follicle-fibrous cyst and a follicle-luteinised cyst (based on histological structure) for anovulatory structures with an overall diameter and wall thickness of $\geq 20$ and $\leq 3 \mathrm{~mm}$, and $\geq 20$ and $\geq 3 \mathrm{~mm}$, respectively.

Key words: Corpus luteum, ovary, ovarian cyst, cystic ovaries, dairy cattle

There has been a lack of consistency in terminology used to designate fluid-filled ovarian structures (other than physiological follicles). Clinical diagnosis of these structures was historically done by transrectal palpation, although

*Corresponding author; E-mail: balogh.orsolya@atk.hu; Phone/Fax: 0036 (23) 319-133 
more recently transrectal ultrasonography has also been used. Some histological studies have been done, but apparently a contemporaneous comparison of ultrasonographic and histological features has not been reported. The nomenclature and characteristics of these structures are shown in Table 1.

A key characteristic of fluid-filled ovarian structures is whether they are ovulatory or anovulatory. Regarding the former, it was previously reported (Kastelic et al., 1990b) that $79 \%$ of corpora lutea had a fluid-filled central cavity. Although a corpus luteum (CL) with a cavity is often regarded as nonpathological with progesterone production similar to that of a solid CL (Kito et al., 1986; Carroll et al., 1990; Kastelic et al., 1990a,b; Assey et al., 1993; Foley, 1996; Garcia and Salaheddine, 2000; Hanzen et al., 2000; Perez-Marin, 2009), other authors disagree with this (Zöldág, 1984; Grygar et al., 1997; Gábor et al., 2004). The area of luteinised tissue was not significantly different between corpora lutea with or without a cavity (Kastelic et al., 1990b), but that assessment was based on a two-dimensional image. However, a more physiological assessment would be based on luteal tissue volume, which varies according to the third power of the radius $\left(r^{3}\right)$.

Anovulatory ovarian cysts are commonly defined as fluid-filled structures $\geq 20-25 \mathrm{~mm}$ in diameter that persist $>10$ days in the absence of a CL (Gümen and Wiltbank, 2002; Brito and Palmer, 2004; Vanholder et al., 2006; Parkinson, 2009). Furthermore, these structures have been categorised according to the degree of luteinisation of the wall. In addition, a single ovarian structure, 8 to 15 $\mathrm{mm}$ in diameter that persisted for at least 7 days in the absence of a CL, was defined as a persistent follicle (López-Gatius et al., 2001). Apparently, these latter structures have not been well characterised.

The primary objectives of the current study were to describe the macroscopic and histological features of corpora lutea with a cavity and anovulatory cystic ovarian structures, and to use these morphologic examinations to clarify the nomenclature.

\section{Materials and methods}

\section{Categorisation of abattoir-derived ovaries}

Ovaries were collected from 90 nonpregnant dairy cows at an abattoir within $4 \mathrm{~h}$ after death. No ante mortem data regarding reproductive history were available. Ovaries were placed in a water-bath and imaged with a B-mode ultrasonographic scanner with a 6-8 MHz linear-array transducer (Pie Medical, Maastricht, The Netherlands). Morphologically normal ovarian follicles with a diameter $<2 \mathrm{~cm}$ and wall thickness $<1 \mathrm{~mm}$ (Singh and Adams, 2000) were excluded. Ovarian structures selected for this study included follicles with a wall thickness $\geq 1 \mathrm{~mm}$ and all structures with luteal tissue and a fluid-filled cavity at least $2 \mathrm{~mm}$ in diameter. These structures were categorised as described (Table 2). 
All luteal structures with a visible ovulation papilla were designated as being ovulatory, whereas those without an ovulation papilla were designated as anovulatory. In addition, four solid corpora lutea (without a cavity) were also examined.

\section{Ultrasonographic examinations and calculations}

During ultrasonographic examinations, images were frozen and recorded. For all structures, the average maximal diameter of the overall structure, and a cavity (if present) were determined based on frozen ultrasonographic images measured with internal callipers. For ovulatory structures with a cavity, overall volume and volume of the cavity were calculated (volume $=4 / 3 \times \mathrm{Pi} \times$ radius $^{3}$ ); the difference was the volume of luteal tissue. For the four solid CL, the same formula was used to calculate luteal tissue volume.

\section{Macroscopic examinations and preparation of histological slides}

Digital images were made of intact structures; thereafter, they were opened by cutting with a surgical blade. Opened structures were placed in $4 \%$ formaldehyde solution for at least $24 \mathrm{~h}$, trimmed, routinely embedded in paraffin, and sectioned. Histological slides were prepared and stained with haematoxylin and eosin, Azan blue and Gömöri silver impregnation (Krutsay, 1980).

\section{Histological descriptions}

Histological descriptions were based on the examination of slides with conventional bright-field light microscopy and specialised image-analysis software (CellD, Soft Imaging System GmbH, Münster, Germany). Various aspects of ovulatory and anovulatory structures were determined, as shown in Fig. 1. For ovulatory structures, 10 microscopic fields were examined $(\times 400$ magnification) between Zones 2 and 4 (Fig. 1). The thickness of the connective tissue layer (between the cavity-side of the wall and the first active luteal cell) was measured (20 locations in 10 microscopic fields at $\times 200$ magnification), and the number of large and small luteal cells, fibroblasts/fibrocytes and pycnotic cells were counted. In that regard, luteal cells were classified morphologically, as described (O'Shea et al., 1989; Smith et al., 1994). Large luteal cells were large (diameter $>20 \mu \mathrm{m}$ ) with light cytoplasm and a spherical, large nucleus (diameter $>10 \mu \mathrm{m}$ ) with prominent nucleoli. Small luteal cells were $<20 \mu \mathrm{m}$ in diameter and darker, with pink cytoplasm and an euchromatic nucleus $(<10 \mu \mathrm{m})$. Fibroblasts/fibrocytes were cylindrical cells with a dark and cylindrical nucleus. All cells with a dark cytoplasm and nucleus were deemed pycnotic. Histological analysis of anovulatory structures was done as shown in Fig. 1. 


\begin{tabular}{|c|c|c|c|c|c|}
\hline \multicolumn{6}{|c|}{ Classification and definition of ovarian structures by different authors } \\
\hline & Zemjanis (1970) & McEntee (1990) & Acland (2001) & Brito and Palmer (2004) & Parkinson (2009) \\
\hline $\begin{array}{l}\text { Follicular cyst (cystic folli- } \\
\text { cles) }\end{array}$ & - & $\begin{array}{l}\text { anovulatory, }>2.5 \mathrm{~cm} \text { in } \\
\text { diameter, partial luteinisa- } \\
\text { tion of the wall (theca in- } \\
\text { terna) }\end{array}$ & $\begin{array}{l}\text { anovulatory, thin walled, } \\
\text { partial luteinisation of the } \\
\text { wall (theca interna) }\end{array}$ & $\begin{array}{l}>2-2.5 \mathrm{~cm} \text { in diameter, } \\
<3 \mathrm{~mm} \text { wall thickness, } \\
<1 \mathrm{ng} / \mathrm{ml} \mathrm{P4} \text {, anovulatory }\end{array}$ & $\begin{array}{l}>2.5 \mathrm{~cm} \text { in diameter, } \\
<3 \mathrm{~mm} \text { wall thickness, } \\
\text { persists, anovulatory }\end{array}$ \\
\hline Cystic Graafian follicle & $\begin{array}{l}\text { anovulatory structure, } \\
\text { synonymous condition as } \\
\text { cystic follicles and follicu- } \\
\text { lar cysts, one single cyst } \\
\text { not exceeding } 2.5 \mathrm{~cm} \text { in } \\
\text { diameter, smooth, distinct } \\
\text { fluctuation, relatively thin } \\
\text { wall }\end{array}$ & 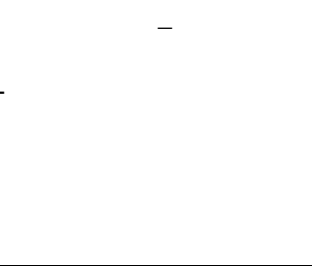 & $\begin{array}{l}>2.5 \mathrm{~cm} \text { in diameter, } \\
\text { persists more than } \\
10 \text { days, anovulatory }\end{array}$ & - & - \\
\hline Luteinised follicles & & $\begin{array}{l}\text { (luteal cyst, luteinised } \\
\text { cyst), anovulatory, large, } \\
\text { spherical cyst, lined by } \\
\text { luteal tissue }\end{array}$ & - & - & $\begin{array}{l}<2.5 \mathrm{~cm} \text { in diameter, } \\
\text { anovulatory, larger cavity } \\
\text { than vacuolated corpus } \\
\text { luteum }\end{array}$ \\
\hline Luteal cyst (luteinised cyst) & $\begin{array}{l}\text { anovulatory structure, } \\
\text { smaller cysts, less distinct } \\
\text { fluctuation, much thicker } \\
\text { wall (layer of luteal tis- } \\
\text { sue) }\end{array}$ & - & $\begin{array}{l}\text { anovulatory, cystic cavity } \\
\text { is lined by fibrous tissue, } \\
\text { surrounded by luteinised } \\
\text { theca cells }\end{array}$ & $\begin{array}{l}>2-2.5 \mathrm{~cm} \text { in diameter, } \\
>3 \mathrm{~mm} \text { wall thickness, } \\
>1 \mathrm{ng} / \mathrm{ml} \mathrm{P4} \text {, anovulatory }\end{array}$ & $\begin{array}{l}>2.5 \mathrm{~cm} \text { in diameter, } \\
>3 \mathrm{~mm} \text { wall thickness, } \\
\text { persists, anovulatory }\end{array}$ \\
\hline Cystic corpus luteum & $\begin{array}{l}\text { practically all characteris- } \\
\text { tics are the same as CLs, } \\
\text { feeling of fluctuation }\end{array}$ & $\begin{array}{l}\text { ovulatory cyst, zone of fi- } \\
\text { brous tissue between the } \\
\text { luteal cells and the cystic } \\
\text { cavity, larger than a nor- } \\
\text { mal CL }\end{array}$ & $\begin{array}{l}\text { forming after ovulation, } \\
\text { large irregular cyst }\end{array}$ & - & - \\
\hline Vacuolated corpora lutea & - & - & - & - & $\begin{array}{l}\text { normal structure, same } \\
\text { size as non-vacuolated CL } \\
\text { but slightly softer palpa- } \\
\text { tion, evidence of ovula- } \\
\text { tion point }\end{array}$ \\
\hline
\end{tabular}


Table 2

Criteria used for grouping ovarian structures

\begin{tabular}{lccccc}
\hline Ovulatory & Group & No. of structures & Diameter $(\mathrm{cm})$ & Cavity $(\mathrm{cm})$ & Wall $(\mathrm{mm})$ \\
\hline \multirow{2}{*}{ Yes } & A & $\mathrm{n}=6$ & $>1.6$ & $\leq 1$ & $>10$ \\
& $\mathrm{~B}$ & $\mathrm{n}=4$ & $>1.6$ & $>1$ & $<10$ \\
\hline \multirow{2}{*}{ No } & C & $\mathrm{n}=8$ & $\leq 2$ & - & $1-3$ \\
& D & $\mathrm{n}=5$ & $>2$ & - & $>3$ \\
\hline
\end{tabular}

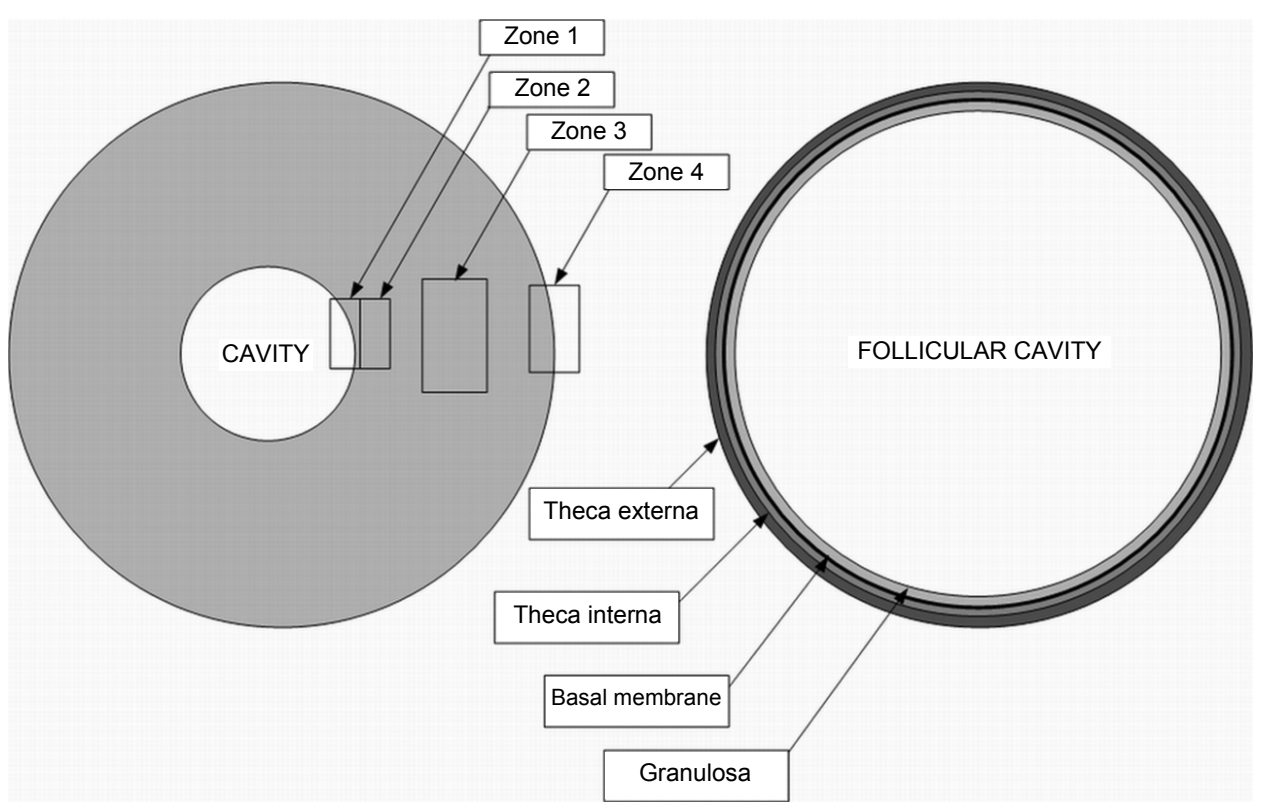

Fig. 1. Layers of ovarian structures studied by light microscopy (left: Groups A and B; right: Groups C, D and E)

\section{Statistical analyses}

A mixed model analysis of variance (ANOVA) was used to compare, among Groups A to E, overall diameter, cavity diameter, and wall thickness. If there was an effect of group ( $\mathrm{P}<0.05$ ), a least significant difference (LSD) test was used to locate differences. In addition, the same analysis was used to compare, among solid CL and Groups A and B, luteal tissue volume and numbers of small luteal cells, large luteal cells, fibroblasts/fibrocytes, and pycnotic cells. Furthermore, for each cell category, the proportion of the total number of cells 
that they represented was calculated and the same statistical approach was used (if proportions were $<0.1$, an arcsine transformation was done, and the transformed data analysed). A Student's $t$-test was used to compare thickness of the connective tissue layer in Group A versus Group B. All statistical analyses were conducted with SAS software (version 2.0.3, October 2008; SAS Institute, Cary, $\mathrm{NC}$, USA). For all end-points with multiple measurements, the average was used for statistical analysis. For all statistical analyses, $\mathrm{P}<0.05$ was considered significant.

\section{Results}

\section{Measurements}

There were differences among solid $\mathrm{CL}$ and Groups A to $\mathrm{E}$ for overall diameter, cavity diameter, and wall thickness $(\mathrm{P}<0.0001$ for each; Table 2$)$. The volume of luteal tissue was less $(\mathrm{P}<0.05)$ in Group B than in Group A, whereas a solid CL was intermediate (Table 3).

Table 3

Ultrasonographic measurements of ovarian structures

\begin{tabular}{|c|c|c|c|c|c|c|}
\hline & $\begin{array}{l}\text { CL group } \\
(\mathrm{n}=4)\end{array}$ & $\begin{array}{c}\text { Group A } \\
(\mathrm{n}=6)\end{array}$ & $\begin{array}{c}\text { Group B } \\
(\mathrm{n}=4)\end{array}$ & $\begin{array}{c}\text { Group C } \\
(\mathrm{n}=8)\end{array}$ & $\begin{array}{c}\text { Group D } \\
(\mathrm{n}=5)\end{array}$ & $\begin{array}{c}\text { Group E } \\
(\mathrm{n}=4)\end{array}$ \\
\hline Diameter (mm) & $\begin{array}{l}22.3 \\
(1.8)\end{array}$ & $\begin{array}{l}27.5^{\mathrm{AB}} \\
(1.7)\end{array}$ & $\begin{array}{l}22.5^{\mathrm{BC}} \\
(2.1)\end{array}$ & $\begin{array}{l}17.6^{\mathrm{C}} \\
(1.5)\end{array}$ & $\begin{array}{l}31.0^{\mathrm{A}} \\
(1.9)\end{array}$ & $\begin{array}{l}26.2^{\mathrm{AB}} \\
(2.1)\end{array}$ \\
\hline Cavity (mm) & $\begin{array}{l}- \\
-\end{array}$ & $\begin{array}{c}7.2^{\mathrm{C}} \\
(1.8)\end{array}$ & $\begin{array}{l}14.0^{\mathrm{B}} \\
(2.2)\end{array}$ & $\begin{array}{l}14.1^{\mathrm{B}} \\
(1.5)\end{array}$ & $\begin{array}{c}27.8^{\mathrm{A}} \\
(1.9)\end{array}$ & $\begin{array}{l}19.5^{\mathrm{B}} \\
(2.2)\end{array}$ \\
\hline Wall (mm) & $\begin{array}{l}- \\
-\end{array}$ & $\begin{array}{l}10.2^{\mathrm{A}} \\
(0.2)\end{array}$ & $\begin{array}{l}4.2^{\mathrm{B}} \\
(0.3)\end{array}$ & $\begin{array}{c}1.8^{\mathrm{D}} \\
(0.2)\end{array}$ & $\begin{array}{c}1.6^{\mathrm{D}} \\
(0.2)\end{array}$ & $\begin{array}{c}3.4^{\mathrm{C}} \\
(0.3)\end{array}$ \\
\hline
\end{tabular}

${ }^{\text {A-D }}$ Means without a common superscript within a row differ significantly $(\mathrm{P}<0.05)$

There was a greater proportion $(\mathrm{P}<0.05)$ of small luteal cells in Group B compared to a solid CL, whereas Group A was intermediate $(58.6 \pm 5.3,37.4 \pm$ 5.3 and $44.0 \pm 4.4 \%$, respectively; Table 4 ). There were also differences in the numbers of fibroblasts/fibrocytes and pycnotic cells $(\mathrm{P}<0.05$ for each). Finally, connective tissue was thicker $(\mathrm{P}<0.05)$ in Group B than in Group A.

\section{Histological descriptions}

Ovulatory structures. In Group A (CL with cavity $\leq 1 \mathrm{~cm}$ and a wall $>1 \mathrm{~cm}$ ), ultrasonographically there was a clear demarcation between the dark fluid-filled cavity and the homogeneous luteal tissue (Fig. 2a). Overall, the macroscopic appearance of Groups A and B (CL with a small or large cavity, respectively) was 
similar to that of a solid CL. Sometimes a small fibrin-filled vesicle connected directly to the cavity was visible on the surface of the papilla. When the structures were opened, the luteal tissue appeared similar to a solid CL, but all cavities were lined with shiny, grey tissue (Fig. 2b) that was well capillarised (cavity wall with connective tissue, CWCT - Zones 1 and 2). Histologically, there were two major layers of the CWCT (Fig. 3a) detected by Azan staining: (a) collagen fibres in the innermost CWCT and, among these fibres, pycnotic cells or cellular debris (Zone 1); (b) well-capillarised fibrous connective tissue with some normal luteal cells (Zone 2).

\section{Table 4}

Least square means and SEM (in parentheses) of histological characteristics and luteal tissue volume of luteinised ovulatory structures, including solid CL, Group A (cavity $<1 \mathrm{~cm}$, wall $>10 \mathrm{~mm}$ ) and Group B (cavity $>1 \mathrm{~cm}$, wall $<10 \mathrm{~mm}$ )

\begin{tabular}{|c|c|c|c|}
\hline & Solid CL $(n=4)$ & Group A $(n=6)$ & Group B $(n=4)$ \\
\hline \multicolumn{4}{|l|}{ Large luteal cells } \\
\hline No. & $48.6(25.3)$ & $86.2(20.6)$ & $70.1(25.3)$ \\
\hline$\%$ & $39.1(5.7)$ & $28.8(4.6)$ & $26.5(5.7)$ \\
\hline \multicolumn{4}{|l|}{ Small luteal cells } \\
\hline No. & $45.8(59.2)$ & $123.3(48.3)$ & $208.9(59.2)$ \\
\hline$\%$ & $37.4^{\mathrm{B}}(5.3)$ & $44.0^{\mathrm{AB}}(4.4)$ & $58.6^{\mathrm{A}}(5.3)$ \\
\hline \multicolumn{4}{|l|}{ All luteal cells } \\
\hline No. & $94.4(72.9)$ & $209.5(59.5)$ & $279.0(72.9)$ \\
\hline$\%$ & $76.5(4.6)$ & $72.7(3.8)$ & $85.0(4.6)$ \\
\hline \multicolumn{4}{|l|}{ Fibroblasts and fibrocytes } \\
\hline No. & $27.5^{\mathrm{B}}(9.3)$ & $58.8^{\mathrm{A}}(7.6)$ & $33.3^{\mathrm{AB}}(9.3)$ \\
\hline$\%$ & $22.6(3.6)$ & $22.9(2.9)$ & $12.4(3.6)$ \\
\hline \multicolumn{4}{|l|}{ Pycnotic cells } \\
\hline No. & $1.1^{\mathrm{B}}(2.0)$ & $10.9^{\mathrm{A}}(1.6)$ & $4.4^{\mathrm{B}}(2.0)$ \\
\hline$\%$ & $0.9(1.2)$ & $4.4(0.9)$ & $2.6(1.2)$ \\
\hline Connective tissue thickness $(\mu \mathrm{m})$ & $-(-)$ & $153.9^{\mathrm{A}}(38.3)$ & $295.4^{\mathrm{B}}(46.9)$ \\
\hline Luteal tissue volume $\left(\mathrm{cm}^{3}\right)$ & $5.84^{\mathrm{AB}}(1.92)$ & $11.224^{\mathrm{A}}(1.57)$ & $4.72^{\mathrm{B}}(1.92)$ \\
\hline
\end{tabular}

${ }^{A}, \mathrm{~B}$ Means without a common superscript within a row differ significantly $(\mathrm{P}<0.05)$

Under the CWCT, there was a layer of functional luteal cells (similar to a solid CL), albeit with more pycnotic and less mitotic cells (Zone 3). Reticular fibres, similar to a solid CL, were detected in sections stained with Gömöri silver impregnation. Furthermore, in some structures from Groups A and B, there were connective tissue trabeculae, similar to those in a solid CL, present within the luteal tissue. At the margins of the structures (Zone 4), many fibroblasts and fibrocytes were surrounded by loosely organised connective tissue. 


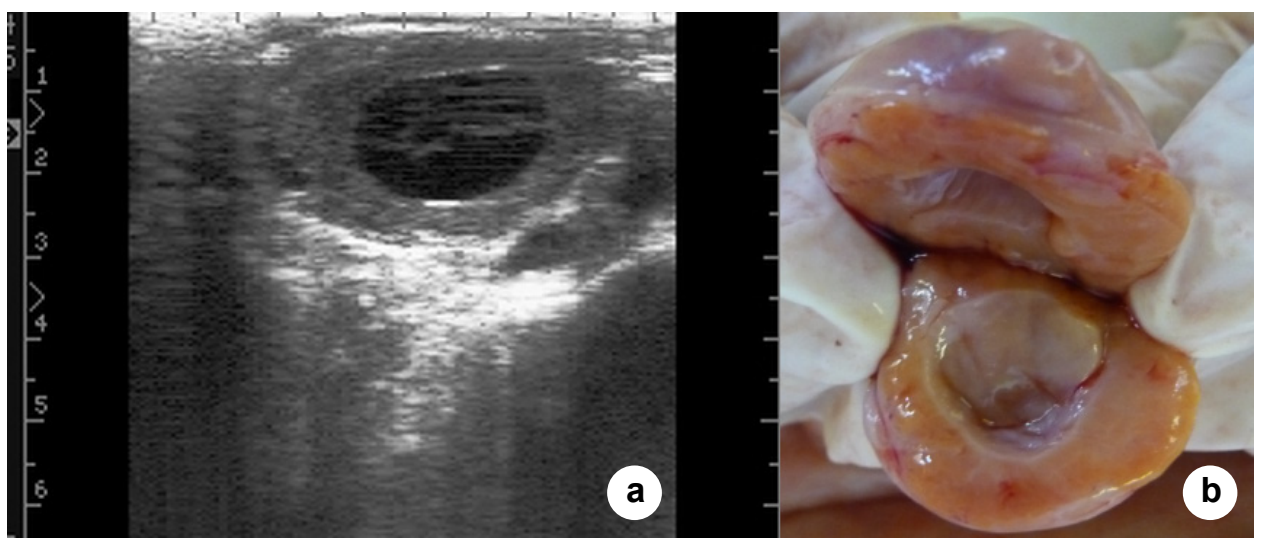

Fig. 2. Group A: (a) left: ultrasonogram of a Group A structure; the intense white line at the top and bottom of the fluid-filled cavity is an artefact (specular reflector); (b) right: a grey, shiny connective tissue layer lined the cavity

In Group B (CL with cavity $>1 \mathrm{~cm}$ and wall $<1 \mathrm{~cm}$ ) the lumen was surrounded by a thick connective tissue layer (Figs $3 a$ and $3 b$ ), with a thinner active luteal cell layer than in Group A (Fig. 4a). Overall, other structural characteristics were similar to Group A (Figs $4 \mathrm{~b}$ and $4 \mathrm{c}$ ).

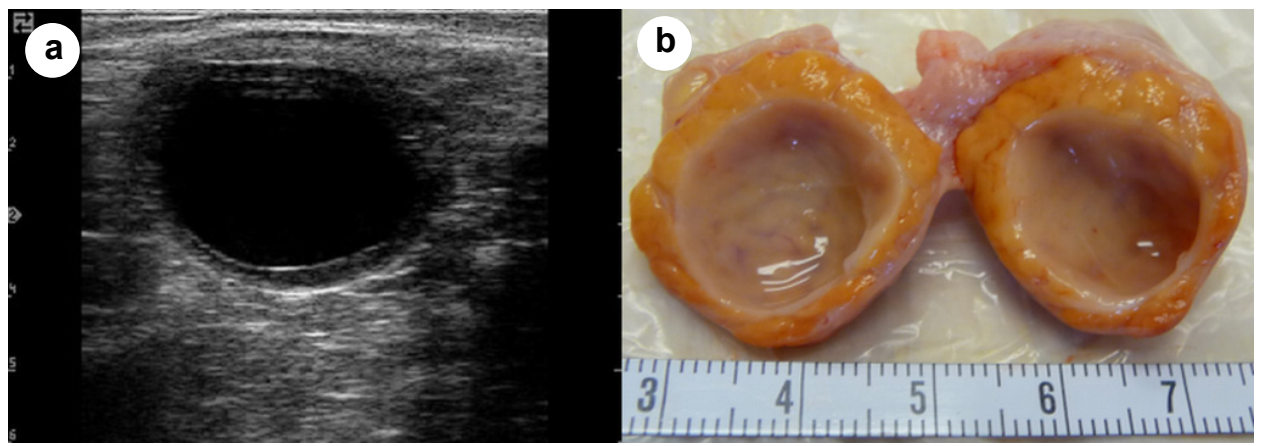

Fig. 3. Group B: (a) left: grey line nearly encircling the cavity; (b) right: note the grey lining and, beneath that, the vivid yellow area of luteinised tissue

\section{Anovulatory structures}

Group $C$. These were fluid-filled structures $<2 \mathrm{~cm}$ in diameter, but with a thick, grey wall (1-3 mm, Fig. 6a). The inner wall of these structures was lined by a thin layer $(1-2 \mathrm{~mm})$ of shiny, grey tissue. This tissue was well vascularised, but no yellow layer was detected (Fig. 6b). In some of these structures, there were two or three layers of granulosa cells on the inner side of the cavity. The basal membrane was recognisable, and underneath there was an active theca in- 
terna (6 to 8 layers), but no luteinisation was detected. The theca externa, which contained well-organised connective tissue, was well vascularised.

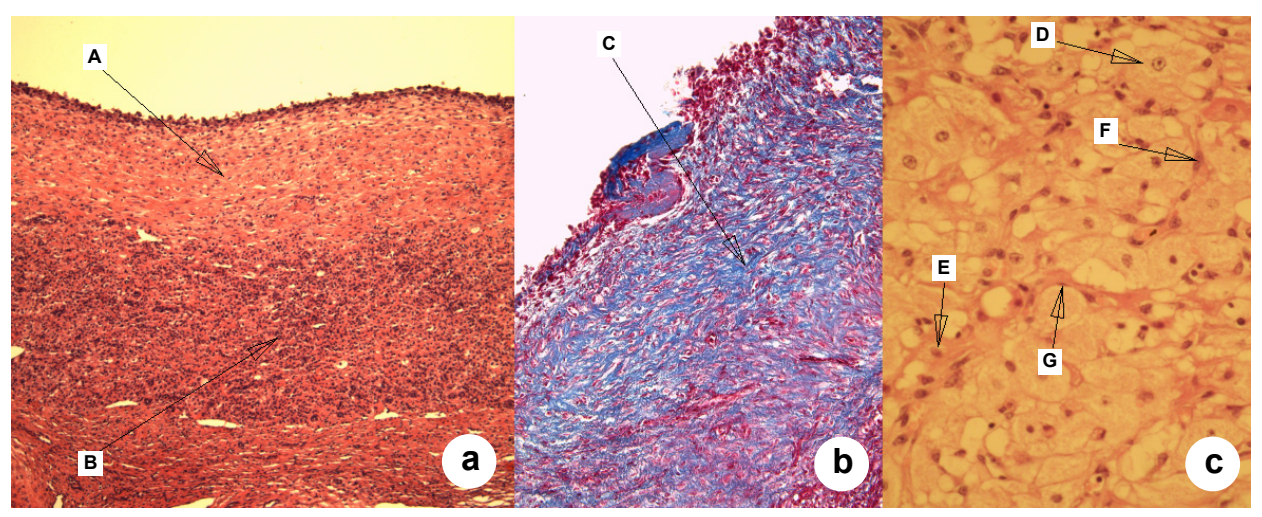

Fig. 4. Group B: (a) left: a thick layer of connective tissue in the cavity wall (arrow A) and, underneath that, an active luteal tissue layer (arrow B; haematoxylin and eosin [HE], $\times 100$ ); (b) middle: massive connective tissue layer (collagen fibres; arrow C) in the cavity wall (Azan staining, $\times 200$ );

(c) right: large (arrow D) and small luteal cells (arrow E), fibroblasts (arrow F) and fibrocytes $($ arrow $\mathrm{G})$ in the luteal tissue $(\mathrm{HE}, \times 400)$

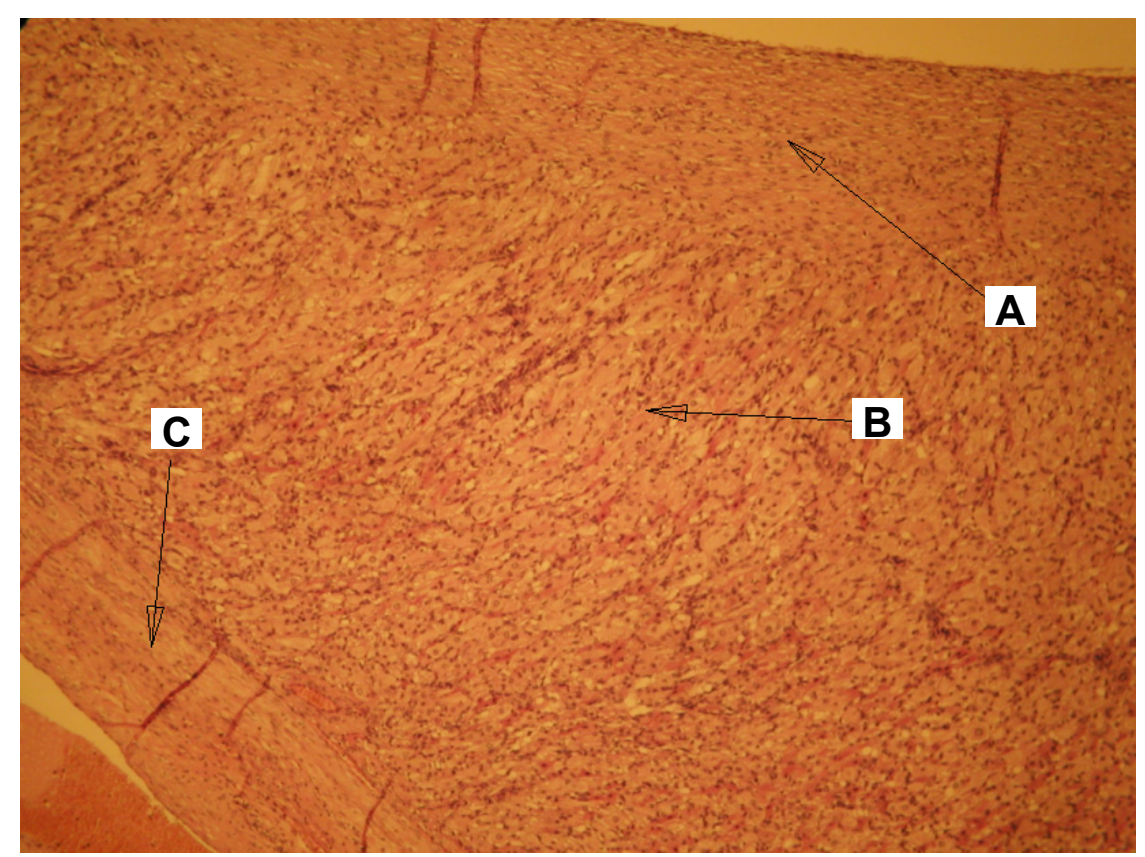

Fig. 5. Group E: on the top, a thick layer of connective tissue (arrow A), beneath it luteinised cells (arrow B) and a distinct connective tissue layer (arrow C) on the far side (no trabeculae present; $\mathrm{HE}, \times 100)$ 


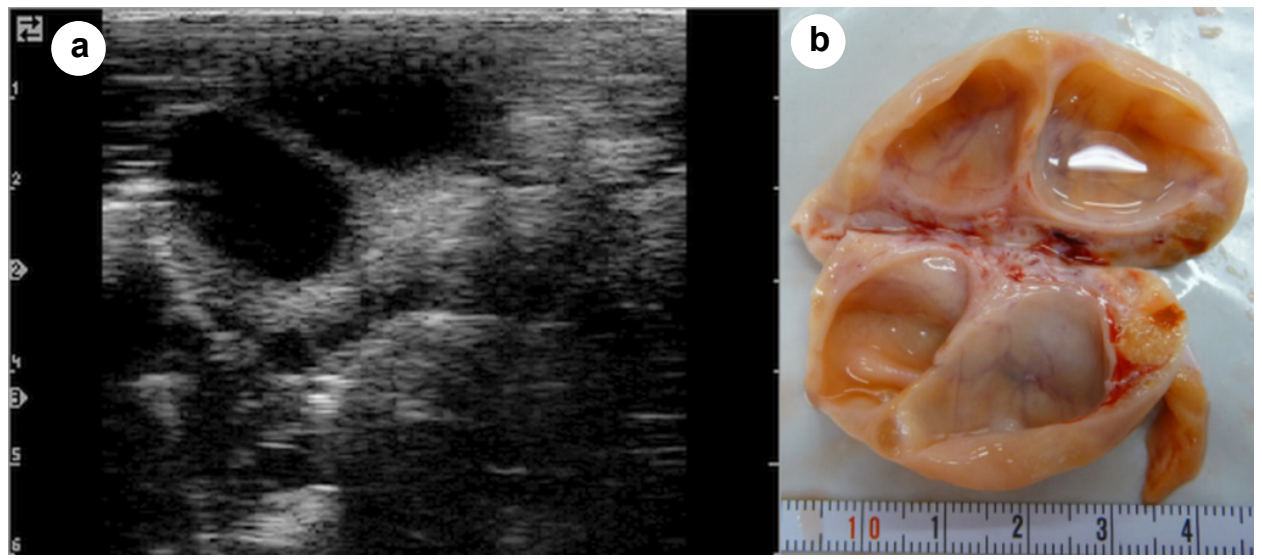

Fig. 6. Group C: (a) left: thickened wall and fluid-filled cavity; (b) right: no ovulation papilla, wellvascularised greyish wall without a yellow layer

Group D. These structures were anovulatory, with a diameter $>2 \mathrm{~cm}$ and a wall thickness $<3 \mathrm{~mm}$. Ultrasonographically, they had a large fluid-filled cavity with a grey wall (Fig. 7a). Macroscopically, they were fluid-filled grey structures with a smooth surface. In some cases, a few yellow spots were present on the inner wall (Fig. 7b). Although the macroscopic and ultrasonic appearance of these phenomena was very similar, histologically there were two distinct types:

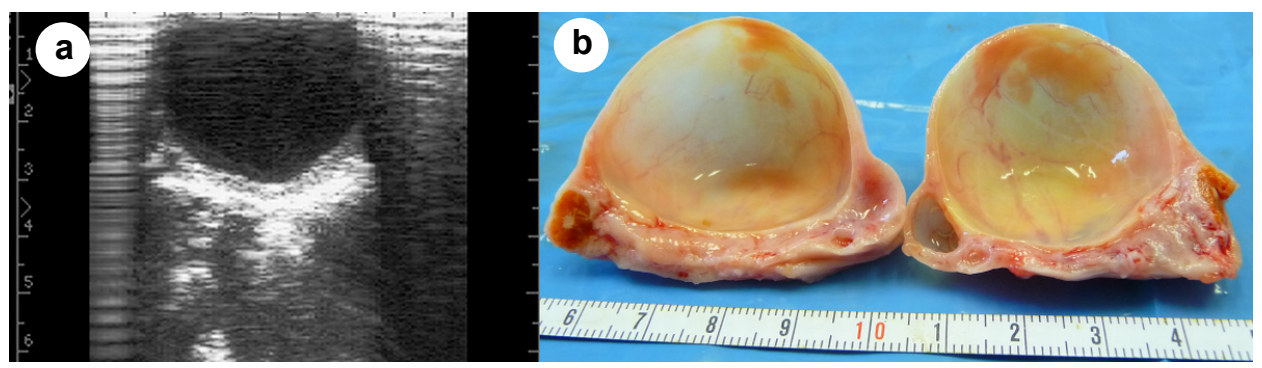

Fig. 7. Group D: (a) left: large cavity and thin wall; (b) right: grey wall with some yellow spots

Type 1: The layers were clearly demarcated. The wall was usually $6-8$ layers (sometimes less), although the granulosa layer was sometimes exfoliated. If the granulosa layer was intact, cells were active but non-luteinised. The basal membrane was usually visible but sometimes it was broken. All theca layers were well-vascularised; active, hormone-secreting cells were present in the theca interna, but the frequency of luteinised cells was low. Theca layers usually consisted of many fibroblasts, capillaries and unorganised connective tissue (sometimes with finer filaments). 
Type 2: The lumen was lined with a thick layer of collagen filaments, with only a few granulosa cells present.

Group E. These were non-ovulatory structures with a diameter $>2 \mathrm{~cm}$ and a wall $>3 \mathrm{~mm}$ thick. Ultrasonographically, they were similar to Group D structures, but their wall was thicker, and occasionally dark-grey extensions into the cavity were visible (Fig. 8a), perhaps representing partial detachment (protrusion) of the wall, attributable to proliferation of luteal tissue. The outer surface was smooth, with a yellow or partly yellow wall, but no ovulation papilla (Fig. 8b). Histologically, there were parallel reticular fibres (connective tissue) around the inner wall of the cavity (detected by Gömöri silver impregnation and Azan staining). These fibres penetrated into the luteinised cell layer, but less regularly than in Groups A or B (no trabeculae were detected; Fig. 5). The theca interna and granulosa layers were not distinguishable; only luteinised cells (mainly large luteal cells) in approximately 15 cell layers were detected. No basal membrane was present, and the outside wall was formed by a theca externa, with fibroblasts and capillaries.

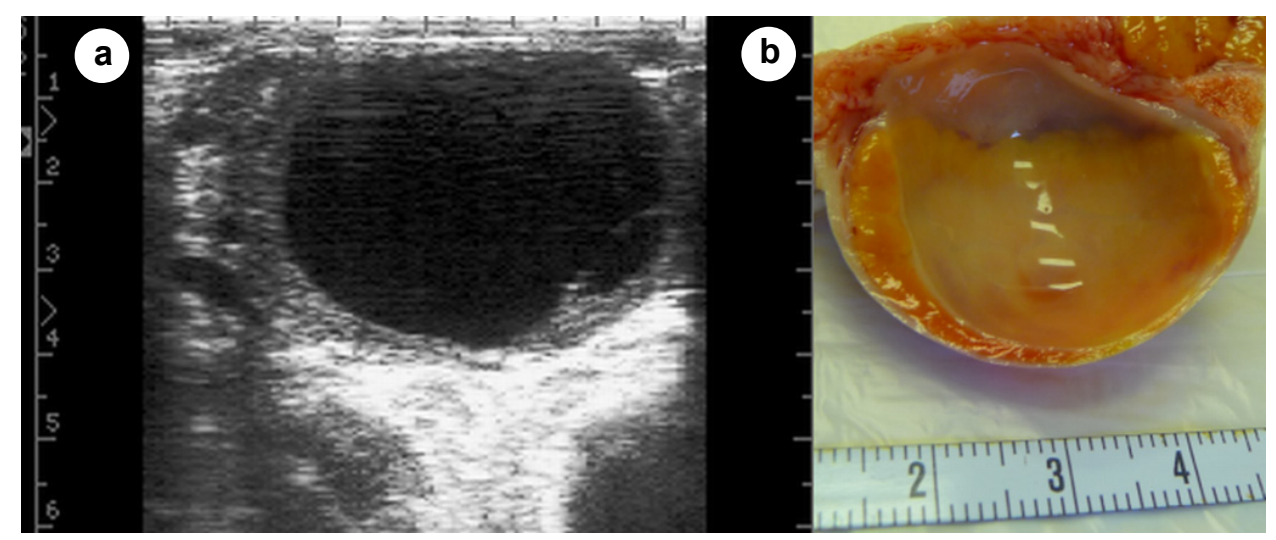

Fig. 8. Group E: (a) left: large, fluid-filled structure, with $>3 \mathrm{~mm}$ thick wall; (b) right: shiny grey lining with an underlying layer of vivid yellow colour

\section{Discussion}

In the present study, on the basis of the presence or absence of an ovulation papilla, ovarian structures were defined as either ovulatory (solid CL and Groups A and B) or anovulatory (Groups C, D and E). Overall, Groups A and B were similar in diameter, although by definition, cavity diameter was smaller but the wall was thicker in Group A than in Group B. Group C had the smallest overall diameter of the anovulatory structures, with a wall thickness not significantly different from that in Group D. 
It was noteworthy that the proportion of small luteal cells was significantly greater in Group B than in solid CL (Group A was intermediate). It was previously reported (Kastelic et al., 1990a) that $79 \%$ of corpora lutea had a cavity at some time during the oestrous cycle; these cavities were first apparent approximately 3 to 5 days after ovulation, and reached a maximum diameter approximately 5.5 to 7.0 days after ovulation. Since all cavities disappeared over time, we inferred that, on average, large cavities would be the youngest luteal structures, a solid CL would be the oldest, and a small cavity would be intermediate. That Group B structures had the largest proportion of small luteal cells was consistent with the prediction that they were the youngest luteal structures, since it is well established that some small luteal cells become large luteal cells over time (Alila and Hansel, 1984; O'Shea et al., 1989; Lopez-Diaz and Bosu, 1992). Furthermore, the present findings were consistent with a previous report (Okuda et al., 1988) of more small luteal cells in a CL with a cavity than in a solid CL.

Connective tissue thickness was significantly less in Group A than Group B. Connective tissue forms after differentiation of granulation tissue (formation of collagen and elastic fibres) from the adventitia of blood vessels (Kissane et al., 1985; van Sickle et al., 1993). Perhaps the connective tissue lining the cavity was due to post-ovulation proliferation and response to tissue damage due to hydrostatic pressure of the liquid. In that regard, Group B structures, with their larger cavities, would be expected to have more damage and consequently more connective tissue. Furthermore, between the fibres of connective tissue layers, there were some damaged luteal cells.

Luteal tissue volume of Group A structures was significantly larger than that of Group B. In a previous study (Kastelic et al., 1990b), there was no significant difference between luteal tissue area in corpora lutea with or without a cavity. However, that previous assessment was based on a two-dimensional image, whereas the present study compared luteal tissue volume, which should be a more physiological assessment, as volume varies according to the third power of the radius $\left(\mathrm{r}^{3}\right)$. There are conflicting reports regarding differences in blood progesterone concentrations in cattle with a solid CL versus a CL with a cavity. In some studies, there was no significant difference (Kito et al., 1986; Kastelic et al., 1990a,b; Veronesi et al., 2002), although there is one report of a difference (Simoes et al., 2007). However, the statistical power to detect real biological differences may have been low due to the blood sampling regimens used (typically a single sample per animal). Furthermore, although most authors stated that a CL with cavity maintained pregnancy (Kito et al., 1986; Carroll et al., 1990; Kastelic et al., 1990a,b; Assey et al., 1993; Foley, 1996; Garcia and Salaheddine, 2000; Hanzen et al., 2000; Perez-Marin, 2009), others concluded that the presence of a cavity had deleterious effects on the cycle and on fertility (Zöldág, 1984; Grygar et al., 1997; Gábor et al., 2004). Furthermore, in another study, the presence of a cavity increased the probability of late embryonic loss (Hatvani et al., 2009). 


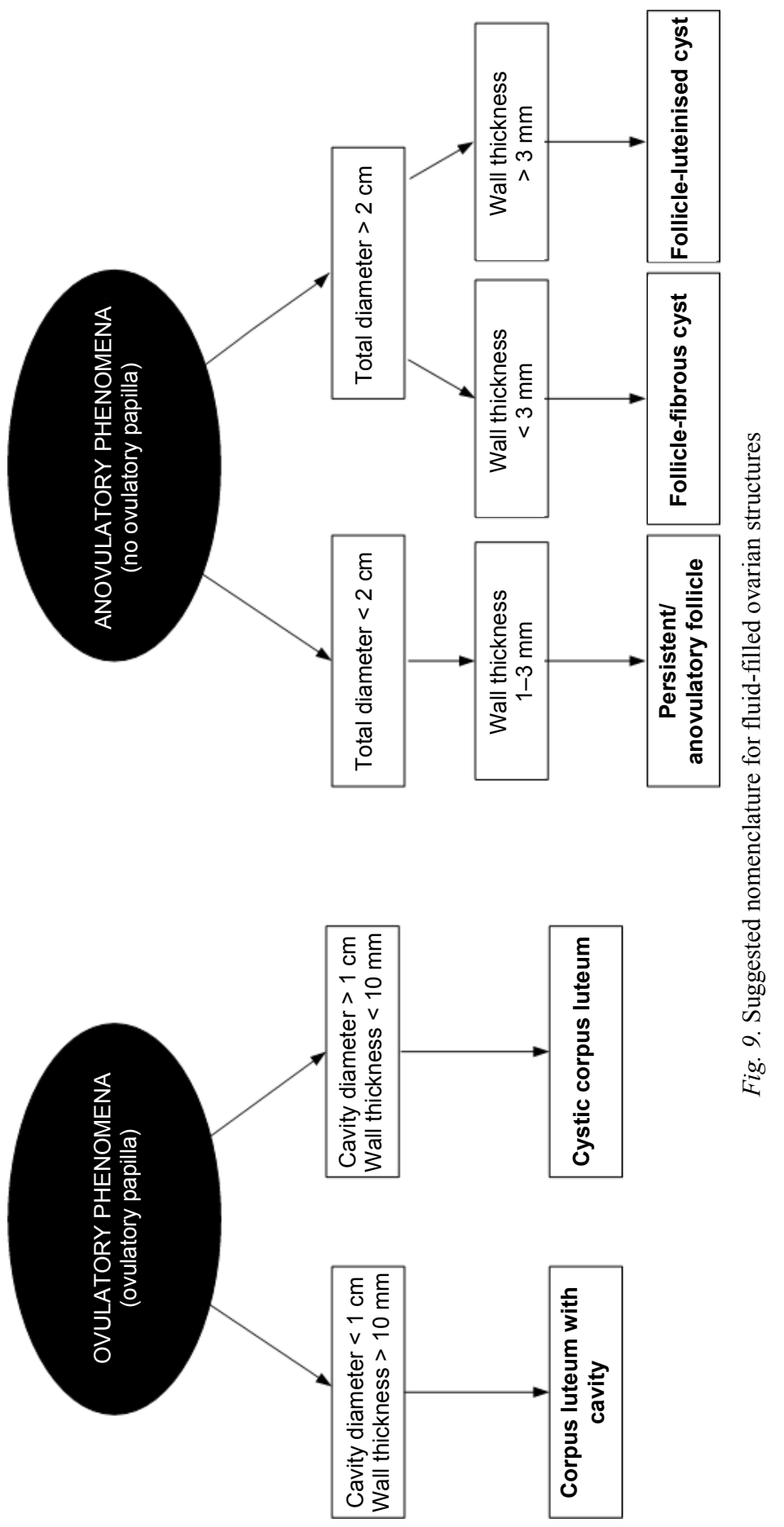


Group A structures had an ultrasonographic morphology similar to a solid $\mathrm{CL}$, except that they also had a non-echodense cavity $<1 \mathrm{~cm}$ diameter with a limited layer of connective tissue surrounding the cavity, and a wall at least $10 \mathrm{~mm}$ thick. Therefore, we suggest that these structures should be designated as a CL with a cavity. In contrast, we suggest that Group B structures, with a cavity $>1 \mathrm{~cm}$, a well-marked CWCT, and total wall thickness $<10 \mathrm{~mm}$, should be designated as cystic CL, consistent with a similar, previous assertion (McEntee, 1990).

By definition, anovulatory structures are follicles that failed to ovulate. Although the exact pathogenesis of failure to ovulate is unknown, the general consensus is that there is hypothalamic-pituitary dysfunction (Garverick, 1997; Gümen and Wiltbank, 2002; Vanholder et al., 2006). Classification of these structures is usually based on their size, persistence, blood progesterone concentrations, and absence of a concurrent CL (Calder et al., 2001; Gümen and Wiltbank, 2002; Brito and Palmer, 2004; Vanholder et al., 2006; Parkinson, 2009). Isobe et al. (2005) allocated cystic follicles into two groups, based on the presence or absence of granulosa cells. Boos et al. (1988) distinguished folliculartheca and follicular-luteinised cysts, based on the macroscopically visible, continuous thick layer of luteal tissue in the latter.

Ultrasonographic and histologic appearances of phenomena in Group C (diameter $<2 \mathrm{~cm}$, wall $1-3 \mathrm{~mm}$, and no ovulatory papilla) were somewhat similar to a normal follicle. However, their thicker wall consisted mainly of connective tissue, and only a few (or no) granulosa cell layers and no luteal cells. Based on these attributes, these structures were consistent with anovulatory/persistent follicles previously reported. In that regard, López-Gatius et al. (2001) described the negative effects of persistent follicles, whereas Bigelow and Fortune (1998) reported higher blood concentrations of 17-beta-oestradiol produced by persistent versus normal dominant follicles. Furthermore, Ahmad et al. (1995) suggested higher rates of early embryonic losses due to elevated 17-beta-oestradiol concentrations.

Phenomena in Group D (diameter $>2 \mathrm{~cm}$, wall $<3 \mathrm{~mm}$, no ovulatory papilla) also had similar macroscopic structure as follicles; however, differences included size, wall thickness and the presence of yellow spots on the inner side of the wall. Histologically, they either had layers similar to those in a follicle (with some luteinised cells in the theca interna layer) or their wall consisted of only some desquamated granulosa cells and thick connective tissue (Types 1 and 2 , respectively). Acland (2001) described cysts with partial luteinisation in the theca cell zone, similar to our Type 1 cysts. Furthermore, it was reported (McEntee, 1990) that in the later stages of cyst formation, granulosa cells undergo pycnosis and karyorrhexis and slough into the cyst cavity, then theca interna cells undergo pycnosis with subsequent fibrosis of the cyst wall; it was noteworthy that these descriptions were similar to Type 2 cysts in our examinations. Perhaps the presence of luteal tissue accounts for regression of some of these structures 
following a single prostaglandin treatment, as reported recently (Hatvani et al., 2013). A categorisation of cysts similar to ours was made by Bamberg et al. (1981). Nakama (1976) and Braw-Tal et al. (2009) described three types of anovulatory, non-luteinised cysts, similar to the present findings, but including a type which was intermediate between the two stages described in the present study. Although these structures are usually termed as 'follicular cyst', to make it clear that not only this type of cyst is forming from anovulatory follicles, and based on the substantial presence of connective tissue fibres, the term 'folliclefibrous cysts' is suggested.

Large anovulatory cysts with almost continuous luteinisation in their wall (visible by ultrasound and also macroscopically) had a completely different histological structure than other anovulatory cysts (Group E: diameter $>2 \mathrm{~cm}$, wall $>3 \mathrm{~mm}$, no ovulation papilla). Their microscopic appearance was more similar to a CL; collagen fibres around the cystic cavity penetrated into the luteinised cell layer, but less regularly (no trabecules) than in ovulatory structures. Luteinised cells were primarily large luteal cells, but a few small luteal cells were also present. Boos et al. (1988) reported compact luteal tissue patches of various size and shape deep in the layers of the cyst. Nakama's (1976) Type IV cysts, Bamberg et al.'s (1981) Type III cysts and Acland's (2001) anovulatory luteinised cysts were similar to our group E structures (only theca layers were present, in a highly luteinised form). Similar histological layers in luteinised cysts were also reported by Hundschell (1978), Leidl et al. (1979) and Peukert-Adam (1981). In a CL, small luteal cells (of thecal origin) are believed to ultimately develop into large luteal cells. The presence, in the luteinised theca layer, of luteinised follicular cyst of cells identical to large luteal cells of the CL might be explained by the potential capacity of small luteal cells to transform into large luteal cells. Similar comparisons between CL and highly luteinised cysts were made by Zöldág et al. (1986); they concluded that a follicular-lutein cyst had the same evolution as a CL. Therefore, based on their anovulatory status and substantial luteinised cell content, we suggest that designating these structures as a 'follicle-luteinised cyst' is more appropriate than designating them as a luteal cyst.

The high prevalence of fluid-filled structures in bovine ovaries (Balogh et al., 2012) and the inconsistency in terminology provide ample justification for further investigations and refinement of terminology. Macroscopic, ultrasonographic, and histological features should help in categorising these structures. The presence (and thickness) of the connective tissue layer around a central cavity may be due to persistence of the structure. Differences in cell distribution (small luteal cells, fibroblasts/fibrocytes, pycnotic cells), connective tissue thickness and luteal tissue volume were consistent with differentiation of CL with cavity and cystic CL. Due to several transient forms, differentiation of nonovulatory phenomena is more difficult, but (1) the absence of an ovulation papilla, (2) overall diameter and (3) wall thickness should provide criteria that 
would usually ensure a correct diagnosis based on ultrasonographic examination of these structures. In that regard, based on the present study, the authors' recommendations regarding nomenclature are summarised in Fig. 9. It is expected that these suggestions will stimulate further investigations and debate in this important aspect of bovine reproduction.

\section{Acknowledgements}

This work was supported by the Hungarian Scientific Research Fund (OTKA 73805). The authors thank Gabriella Gombár (Department of Anatomy and Histology, Faculty of Veterinary Science, Szent István University, Budapest, Hungary) and Dr. Edit Babarczi (Department of Pathology and Histopathology, Szent István Hospital, Budapest, Hungary) for preparing the histological slides.

\section{References}

Acland, H. M. (2001): Reproductive system: female. In: McGavin, M. D., Carlton, W. W. and Zachary, J. F. (eds) Thomson's Special Veterinary Pathology. Mosby Inc., St. Louis, Missouri. pp. 512-543.

Ahmad, N., Schrick, F. N., Butcher, R. L. and Inskeep, E. K. (1995): Effect of persistent follicles on early embryonic losses in beef cows. Biol. Reprod. 52, 1129-1135.

Alila, H. W. and Hansel, W. (1984): Origin of different cell types in the bovine corpus luteum as characterized by specific monoclonal antibodies. Biol. Reprod. 31, 1015-1025.

Assey, R. J., Purwantara, B., Greve, T., Hyttel, P. and Schmidt, M. H. (1993): Corpus luteum size and plasma progesterone levels in cattle after cloprostenol-induced luteolysis. Theriogenology 39, 1321-1330.

Balogh, O. G., Fébel, H., Huszenicza, Gy., Kulcsár, M., Abonyi-Tóth, Zs., Endrődi, T. and Gábor, Gy. (2012): Seasonal fertility differences in synchronised dairy cows: Ultrasonic, metabolic and endocrine findings. Acta Vet. Hung. 60, 131-143.

Bamberg, E., Choi, H. S., Mostl, E., Klaring, W. J. and Stockl, W. (1981): Steroidhormongehalt und Aromatasenaktivitat in Ovarialzysten des Rindes. Zbl. Vet. Med. 28, 366-372.

Bigelow, K. L. and Fortune, J. E. (1998): Characteristics of prolonged dominant versus control follicles: follicle cell numbers, steroidogenic capabilities, and messenger ribonucleic acid for steroidogenic enzymes. Biol. Reprod. 58, 1241-1249.

Boos, A., Wittkowski, G. and Schwarz, R. (1988): Activity of alkaline phosphatase in uterine flushings of dairy cows affected with ovarian cysts or endometritis. Theriogenology 30, 217-225.

Braw-Tal, R., Pen, S. and Roth, Z. (2009): Ovarian cysts in high-yielding dairy cows. Theriogenology 72, 690-698.

Brito, L. F. C. and Palmer, C. W. (2004): Cystic ovarian disease in cattle. Large animal veterinary rounds 4 (10) http://www.larounds.ca/crus/laveng_1204.pdf

Calder, M. D., Manikkam, M., Salfen, B. E., Youngquist, R. S., Lubahn, D. B., Lamberson, W. R. and Garverick, H. A. (2001): Dominant bovine ovarian follicular cysts express increased levels of messenger RNAs for luteinizing hormone receptor and 3-beta-hydroxisteroid dehydrogenase delta(4), delta(5) isomerase compared to normal dominant follicles. Biol. Reprod. $\mathbf{6 5}, 471-476$. 
Carroll, D. J., Pierson, R. A., Hauser, E. R., Grummer, R. R. and Combs, D. K. (1990): Variability of ovarian structures and plasma progesterone profiles in dairy cows with ovarian cysts. Theriogenology 34, 349-370.

Foley, G. L. (1996): Pathology of the corpus luteum of cows. Theriogenology 45, 1413-1428.

Gábor, G., Tóth, F. and Mézes, M. (2004): Preliminary comparison of luteal cavity size with some serum metabolic parameters in dairy cows. Biol. Reprod. 790 (Special Issue), SI 274.

Garcia, A. and Salaheddine, M. (2000): Ultrasonic morphology of the corpora lutea and central luteal cavities during selection of recipients for embryo transfer. Reprod. Dom. Anim. 35, $113-118$.

Garverick, H. A. (1997): Ovarian follicular cysts in dairy cows. J. Dairy Sci. 80, 995-1004.

Grygar, I., Kudláč, E., Doležel, R. and Nedbálková, J. (1997): Volume of luteal tissue and concentration of serum progesterone in cows bearing homogeneous corpus luteum or corpus luteum with cavity. Anim. Reprod. Sci. 49, 77-82.

Gümen, A. and Wiltbank, M. C. (2002): An alteration in the hypothalamic action of estradiol due to lack of progesterone exposure can cause follicular cysts in cattle. Biol. Reprod. 66, $1689-1695$.

Hanzen, C. H., Pieterse, M., Szenci, O. and Drost, M. (2000): Relative accuracy of the identification of ovarian structures in the cow by ultrasonography and palpation per rectum. Vet. J. 159, 161-170.

Hatvani, C., Balogh, O. G., Endrődi, T., Abonyi-Tóth, Z., Holló, I., Kastelic, J. and Gábor, G. (2013): Estrus response and fertility after a single cloprostenol treatment in dairy cows with various ovarian structures. Can. J. Vet. Res. 77, 218-220.

Hatvani, C., Balogh, O. G., Holló, I. and Gábor, G. (2009): Postpartum and post-insemination frequency of irregular luteal forms on a Hungarian dairy cattle farm [in Hungarian, with English abstract]. Magyar Állatorvosok Lapja 11, 647-650.

Hundschell, C. (1978): Untersuchungen zum Hormongehalt bei Follikelzysten (Follikel-Thecaund Follikel-Lutein-Zysten) im Blut und in der Zystenflüssigkeit sowie zum Auftreten von zyklischen Vorgängenan den Ovarien beim Bestehen von Follikelzysten beim Rind. Dissertation, Faculty of Veterinary Medicine, University of Munich.

Isobe, N., Kitabayashi, M. and Yoshimura, Y. (2005): Microvascular distribution and vascular endothelial growth factor expression in bovine cystic follicles. Dom. Anim. Endocrin. 29, 634-645.

Kastelic, J. P., Bergfelt, D. R. and Ginther, O. J. (1990a): Relationship between ultrasonic assessment of the corpus luteum and plasma progesterone concentration in heifers. Theriogenology 33, 1269-1278.

Kastelic, J. P., Pierson, R. A. and Ginther, O. J. (1990b): Ultrasonic morphology of corpora lutea and central luteal cavities during the estrus cycle and early pregnancy in heifers. Theriogenology 34, 487-498.

Kissane, J. M., Anderson, W. A. D. and Marchesi, V. T. (1985): Inflammation and healing. In: Anderson, W. A. D. (ed.) Anderson's Pathology. Volume 1. 8th edition. The C. V. Mosby Company, St. Louis. p. 58.

Kito, S., Okuda, K., Miyazawa, K. and Sato, K. (1986): Study on the appearance of the cavity in the corpus luteum of cows by using ultrasonic scanning. Theriogenology 25, 325-333.

Krutsay, M. (1980): Histological Techniques [in Hungarian]. Medicina Könyvkiadó, Budapest.

Leidl, W., Stolla, R., Hundschell, C. and Bostedt, H. (1979): Zur Ovarialzyste des Rindes. I. Klassifizierung und Diagnose. Berl. Münch. Tierärztl. Wschr. 92, 369-376.

Lopez-Dias, M. C. and Bosu, W. T. K. (1992): A review and an update of cystic ovarian degeneration in ruminants. Theriogenology 37, 1163-1183.

López-Gatius, F., Santolaria, P., Yániz, J., Ruttlant, J. and López-Béjar, M. (2001): Persistent ovarian follicles in dairy cows: A therapeutic approach. Theriogenology 56, 649-659.

McEntee, K. (1990): Cysts in and around the ovary. In: McEntee, K. (ed.) Reproductive Pathology of Domestic Mammals. Academic Press Inc., San Diego, California. pp. 52-59. 
Nakama, S. (1976): Enzyme-histochemical studies on normal and cystic ovaries in the cow and sow. Bull. Univ. Osaka Pref. Series B 28, 19-98.

Okuda, K., Kito, S., Sumi, N. and Sato, K. (1988): A study of the central cavity in the bovine corpus luteum. Vet. Rec. 13, 180-183.

O'Shea, J. D., Rodgers, R. J. and D'Occhio, M. J. (1989): Cellular composition of the cyclic corpus luteum of the cow. J. Reprod. Fert. 85, 483-487.

Parkinson, T. (2009): Infertility and subfertility in the cow: structural and functional abnormalities, management deficiencies and non-specific infections. In: Noakes, D. E., Parkinson, T. J. and England, G. C. W. (eds) Veterinary Reproduction and Obstetrics. Saunders Elsevier, Philadelphia. pp. 439-448.

Perez-Marin, C. (2009): Formation of corpora lutea and central luteal cavities and their relationship with plasma progesterone levels and other metabolic parameters in dairy cattle. Reprod. Dom. Anim. 44, 384-389.

Peukert-Adam, I. (1981): Makro- und mikromorphologische Untersuchungen an Follikel-LuteinZysten des Rindes. Dissertation, Tierärztl. Hochschule, Hannover.

Simoes, J., Almeida, J. C., Baril, G., Azevedo, J., Fontes, P. and Mascarenhas, R. (2007): Assessment of luteal function by ultrasonographic appearance and measurement of corpora lutea in goats. Anim. Reprod. Sci. 97, 36-46.

Singh, J. and Adams, G. P. (2000): Histomorphometry of dominant and subordinate bovine ovarian follicles. Anat. Rec. 258, 58-70.

Smith, M. F., McIntush, E. W. and Smith, G. W. (1994): Mechanisms associated with corpus luteum development. J. Anim. Sci. 72, 1857-1872.

Vanholder, T., Leroy, J. L. M. R., Van Soom, A., Maes, D., Coryn, M., Fiers, T., de Kruif, A. and Opsomer, G. (2006): Effect of non-esterified fatty acids on bovine theca cell steroidogenesis and proliferation in vitro. Anim. Reprod. Sci. 92, 51-63.

Van Sickle, D. C., Dellmann, H. D. and Brown, E. M. (1993): Connective and supportive tissues. In: Dellmann, H. D. (ed.) Textbook of Veterinary Histology. Lea \& Febiger, Philadelphia, USA. p. 29.

Veronesi, M. C., Gabai, G., Battocchio, M., Mollo, A., Soldano, F., Bono, G. and Cairoli, F. (2002): Ultrasonographic appearance of tissue is a better indicator of CL function than CL diameter measurement in dairy cows. Theriogenology $\mathbf{5 8}, 61-68$.

Zemjanis, R. (1970): Examination of the cow: Changes in the ovaries and oviducts. In: Zemjanis, R. (ed.) Diagnostic and Therapeutic Techniques in Animal Reproduction. The Williams \& Wilkins Company, Baltimore, USA. pp. 67-69.

Zöldág, L. (1984): Ovarian cysts in dairy cattle. I. Differential diagnosis of follicular and luteal cysts [in Hungarian, with English abstract]. Magyar Állatorvosok Lapja 39, 467-470.

Zöldág, L., Vetési, F., Solti, L. and Molnár, L. (1986): Comparative endocrinological and morphologic studies of the cyclic corpus luteum and follicular-luteinic cyst in cattle [in Hungarian, with English abstract]. Magyar Állatorvosok Lapja 41, 343-347. 